\title{
Exploration and Research on the Training Mode of Mechanical Talents in Applied Undergraduate Colleges
}

\author{
ZHONG Lijun \\ Baicheng Normal University, Baicheng, 137000, China \\ email:jlsbcsfxy@163.com
}

Keywords: Applied Undergraduate Colleges, Mechanical Talents, Training Mode

\begin{abstract}
Application-oriented colleges and universities refer to schools that meet the needs of social applications. This paper mainly aims at the demand of the society for mechanical talents, the goal and result of mechanical talents training in applied undergraduate colleges, and analyzes and explores the main contents of the current training mode of mechanical talents in colleges and universities. This paper puts forward the problems caused by the talent training model, and, according to these problems, innovates on the basis of the current talent training model, which combines practice with theoretical knowledge in colleges and universities. Finally, a new type of talent training model is summed up to meet the current social needs and school training objectives.
\end{abstract}

\section{Introduction}

With the development of the society, various industries in our country have developed relatively. Among them, the manufacturing industry based on the specialty of machinery, the assembly of electronic equipment, and the enterprises supporting the technology of instruments and so on have developed relatively well. Therefore, it also determines the large demand for mechanical talents in our country at present, which is also the main task of our country's undergraduate colleges and universities at present. However, the actual research results show that even the students who choose mechanical majors in recent years have once again reached a new high. The major mechanical enterprises are still facing the situation of talent vacancy, and many students are facing the situation of finding a job at the same time. Therefore, in order to understand this situation, this paper requires the society to demand talents. In order to meet the needs of the society, this paper optimizes the relevant measures and updates the training model in order to meet the needs of the society.

\section{The Connotation and Classification of Applied Talent Training Model}

This section is mainly based on the relevant research materials to investigate and summarize, to study the main connotation of various applied talents training model and focus on the type, the application of training means refers to the practice level as the main teaching standard of a teaching means, therefore, In order to solve the problem of pure learning mode, the investigation shows that the students are less efficient in receiving theoretical knowledge, learning theoretical knowledge is boring, and it is very difficult to arouse learning interest. In order to guarantee the quality of professional talents, the major of colleges and universities in our country often adopts various training modes to carry out education and teaching in the course of ordinary education and teaching. In most of the teaching modes, the dual teaching mode is often adopted in our country. Dual teaching mode means that, on one hand, students are taught theoretical knowledge according to the requirements of teaching materials; on the other hand, they provide as many practical opportunities as possible to deeply understand the theoretical knowledge in practice. In the theoretical study, associative innovation practice possibility, dual mixed learning[1].In addition, there are also a variety of learning models abroad, such as British universities, most of which are based on collective learning materials, and then require students to rely on their personal strength to practice experience, and finally return to the classroom, before the work of the problem can be solved one by one; The educational model in the United States is more abundant, and the more famous one is that the teaching model of cooperation between schools and enterprises is different from that of the 
United Kingdom. The United States often takes a fixed proportion of personnel to participate in practical work, taking turns to select and participate, and can explore different experiences among them. Through the above analysis, we can find that different countries have different educational models, but their common purpose is to educate application-oriented talents who meet the needs of the society, and to train suitable talents pertinently. In addition to focusing on classroom performance, the level of achievement is more important to practice training and awareness[2].

\section{The Present Situation of Social Demand for Mechanical Talents}

With the development of society, the major industry of our country has gradually tends to specialization, for the demand of various professional talents has reached an all-time high, which, for the social demand for machinery professional talents of higher requirements, because the face is directly close to the equipment research and development technology of our daily life. The use of machinery and manufacturing, so professional mechanical personnel, can directly affect our daily life safety, convenience and so on. According to incomplete statistics, China's top five hundred enterprises, which belongs to the mechanical manufacturing enterprises has reached more than more than 200, more than half of the big enterprise also indicates the urgent needs for the mechanical talents[3].At present, our country mainly belongs to the enterprises in the field of machinery, including the automobile manufacturing industry, the processing of mobile phone parts and devices, the assembly of computer equipment, and so on. These enterprises have a huge demand for talents and the scope of demand, including major designers, engineers, etc. In addition, there is also a greater demand for electricians in the field of machinery, technicians for various kinds of equipment maintenance, and assembly personnel. Take Foxconn as an example, it belongs to an electronic accessories enterprise, mainly focusing on the assembly of mobile phone accessories. The fully mechanized work model, but on some pipeline, workers are needed to assist the machines to complete the assembly tasks. The demand for pipeline employees alone is staggering. Apart from long-term workers, there is an urgent need for a large number of short-term student workers every winter and summer vacation. The total number of Foxconn enterprises in China has reached more than 40. According to the above analysis, there is a great demand for mechanical talents in the society at present, and most of them are jobs that work directly and pay more attention to the actual technical level of individuals.

\section{The Goal of Talent Training in Applied Undergraduate Colleges}

In view of the current situation of social demand, universities and colleges have clear objectives for the cultivation of mechanical talents. Applied undergraduate colleges refer to colleges and universities whose main teaching content is specialized technology. But what distinguishes the undergraduate course from the technical college is rich theoretical knowledge. Therefore, the applied undergraduate college mainly trains the professional talents with theoretical knowledge support. The requirement of cultivating mechanical talents in applied undergraduate colleges is to have the technical talents of innovation and repair under the condition of knowing the mechanism of mechanical operation[4].According to the investigation, most colleges and universities, in the process of teaching mechanical major students, adopt the teaching means of "practice first" to cultivate high-level technical talents. To meet the needs of social development. The goal of undergraduate colleges and universities is mainly to train theoretical professional and technical personnel. The simple explanation is that mechanical students graduated from undergraduate colleges and universities, in addition to mastering many mechanical skills, can work directly. Can clearly grasp the use of equipment principles, at the same time have professional theoretical knowledge, can reach the level of mechanical engineering designers, in addition to simple mechanical repair has rich experience, but also has the concept of mechanical innovation, And professional knowledge of mechanical internal operation principle. 


\section{The Present Situation of the Training Mode of Applied Mechanical Talents}

Pattern content. According to the demand of the society for talents, the universities and colleges have formulated the corresponding training goals of talents, which mainly include the teaching mode based on practical technology, the teaching mode of combining practical knowledge and knowledge, and the teaching mode of theory and scientific research knowledge. However, most applied undergraduate colleges adopt the mode of combining practical technology with theoretical knowledge to carry out education and teaching. As far as our country is concerned, quite a number of schools have already completed the establishment of teaching and research practice in their own schools, and after the study of theoretical knowledge, To quickly lead students to apply practice, test their technical level, and at the same time find out their problems, teachers and students communicate with each other, then the two sides exchange questions, answer them separately, and have the corresponding reward and punishment mechanism set up. In addition to the end-of-term examination system evaluation, there are usually many related competitions. In addition, there are also many colleges and universities that do not have relevant practice bases on their campus. These schools usually require students to find relevant enterprises to conduct internships in the winter and summer vacations. They regularly record the contents of their internships, and eventually hand them over to the school, so that they can start school early. Most of them are to check and summarize the practice certificate and practice experience. In addition, the school organizes students to visit the relevant enterprises, and understands its work content and emphasis, and then summarizes and analyzes it[5].

Existing problems. According to the current investigation on the cultivation of mechanical talents in China's applied undergraduate universities, it can be understood that the training objectives meet the needs of social talents, but the training methods need to be updated. At present, the most popular teaching mode in China is the combination of theoretical knowledge and practice, and its practice is based on its own practice base. In this way, the practice content is limited to a single one, most of the undergraduate colleges and universities are four years old, they generally study major profit-making knowledge and skills in their sophomores, and add a small amount of practice. In the teaching of junior and senior students, all of them are basically practical teaching. But confined to the school practice base, obviously the skill enhancement space is limited[6].And when the school lacks an autologous practice base, it usually requires students to arrange their own internships and increase their practical experience with the help of the winter and summer break. This requires students to be highly conscious, but usually speaking, Students are rarely able to carry out relevant internships in accordance with the requirements of the school. And according to the survey, although there is a great demand for human and mechanical talents in the society at present, for the vast majority of recent graduates graduating from mechanical engineering, The biggest problem is still finding a job. The main reason for this problem is that society has higher requirements for graduates of undergraduate courses, but the actual technical practice level of graduated students is not up to the standard, and they are unwilling to enter the grass-roots level of enterprises. These phenomena show that there are still some problems in the present teaching mode, and the combination of practice and theoretical knowledge is still not realized.

\section{Exploration on the Construction of a New Model for the Cultivation of Mechanical Talents}

Innovation principle. In order to solve the problems encountered by mechanical professionals and enterprises, it is necessary to re-analyze and optimize the teaching mode and solve the root problem of talent training. It is found that many colleges and universities have a clear goal of training, that is, to cultivate suitable social talents, but the final training results show that the real talent is still rare[7].Therefore, on the basis of unchanged training objectives, it is necessary to innovate and optimize the talent training model of undergraduate colleges and universities at the present stage, that is to say, in our country's talent training model, It is still necessary to adopt the teaching mode of combining practice and theory to train talents. According to the result of training, we need to 
increase the training requirements of practice quantity, and at the same time, according to the expectation of the society to the colleges and universities, The importance of theoretical knowledge should not be ignored. The innovation of practice should be enhanced by the relevant teaching equipment, and the theory and practice should be carried out on the basis of this specialty. Increase the strength of practice, but also increase the strength of theoretical knowledge.

Primary coverage. In view of the present situation and results of training mechanical talents in undergraduate colleges and universities, this paper analyzes some problems in the training mode. In order to avoid these problems, the reform and innovation of teaching mode are carried out. According to the above principles, colleges and universities need to strengthen the practice, when the practice learning reaches a certain height, we need to keep the matching of theoretical knowledge and constantly update the theoretical knowledge. The new teaching mode should still adopt the combination of theory and practice[8].In view of the analysis of four-year colleges and universities, the system of learning basic knowledge in the first year remains unchanged, and in the second year, when learning theoretical knowledge, it is necessary to immediately begin to study in a mode that combines practice and practice. After the completion of the study of a subject, the teacher can lead the experiment and analysis in the school's practice base. After each practice, we need to make a relevant summary. In addition, the requirements for the winter and summer vacation practice can still not be changed, but the reward mechanism should be added. This is a fair treatment for those students who really can learn voluntarily. The general competition practice is usually set up in the second semester of a sophomore year to the entire semester of a sophomore year. According to the new model, the competition time can be set according to the original plan. However, the main topics of the competition can be set up on the basis of the actual progress requirements of the enterprises at this stage. Students can sign up for the design without a threshold, and students with excellent design results can directly obtain corporate sponsorship awards; in addition, for junior internships, it can not only be limited to the school practice base, the school should organize students to enter the enterprise practice collectively, and specially equipped with lecturers to explain the practice period of at least one month, after returning to school should be a profound summary of practical experience; In addition, schools need to be strict about the recruitment of lecturers. Lecturers can not only teach their students basic theories, but also have the key skills to lead the practice, so that when the theoretical knowledge is explained and the practice is led into one person, it helps students master knowledge.

\section{Conclusion}

This paper mainly studies the mode of talents training for mechanical majors in applied undergraduate colleges. Through the analysis of the current social demand for talents, the training objectives of the schools, and the contents of the training model of the undergraduate colleges, it is found that a large part of the present Chinese mechanical professionals do not meet the requirements of the state. But the national demand for mechanical talent is very high. The main reason for this problem is the lack of practice in the training of mechanical talents in schools, so increasing practical training has become the main innovative means of the current training mode. But at the same time, we can not ignore the learning of theoretical knowledge. Therefore, this paper creates a new training model to meet the needs of talents in our society, which continues the characteristics of combining practice and theoretical knowledge in the current teaching model. And the way of cooperation between school and enterprise and the practice of college students just accord with the requirement of talent training in our country at present. It is believed that the demand for mechanical talents can be solved greatly by applying this model.

\section{Acknowledgement}

In this paper, the research was sponsored by the Reform of Vocational Education and Adult Education Foundation in the Education Department of Jilin Province in 2016(Project No. 2016ZCY002). 


\section{References}

[1]XUE Ximin. The Present Situation and Development of Shanghai Higher Vocational Education[R].National Symposium on Higher Vocational Education in Undergraduate Colleges and Universities,2010.

[2]The Teaching Reform Scheme of Electromechanical Integration Specialty(2002).Selection and Compilation of the Pilot Program of Teaching Reform for Higher Vocational Education Specialty[M]Beijing: Higher Education Press,2003.

[3]SUN Weimin. Training Students' Engineering Design Ability with Practical Ability as Carrier[J].China Higher Education,2006 (9) :4445.

[4]LIN Jian. Study on the Specialty training Program of "Education and Training Program for Outstanding Engineers"[J].Tsinghua Journal of Education,2012.

[5]SHAO Yijiang, SUN Qinying. Several Links to be Grasped in the Implementation of "Excellence Plan" in Local Colleges and Universities. China University Teaching,2012 .

[6]LIN Jian. Construction of Engineering Teachers for Excellent Engineers[J].Research in Higher Education of Engineering,2012 (1) 4.

[7]PENG Xiaobo, YAN Liping. Analysis of the Employment Difficulties of College Students[J]Pioneering with Science \& Technology Monthly,2008,10,106- 107.

[8]GUAN Yong. The implementation of career Planning for College students[J].China Adult Education,2015,437- 38 